\title{
AUDIT LAG, TENURE, AGE, SIZE, PROFITABILITY AND SOLVENT RESISTANCE TO STOCK VOLATILITY WITH PUBLIC ACCOUNTANT REPUTATION AS MODERATION
}

\author{
Niken Savitri Primasari ${ }^{1}$ \\ Email: niken@unusa.ac.id \\ Mohammad Ghofirin ${ }^{2}$ \\ Email:ghofie@unusa.ac.id
}

\begin{abstract}
Accordance with the principle of transparancy of financial statements and annual reports announce by the public company as an important element to avoid the gap time that might causing potentially negative effects information for investors, which thus delayed information phenomenon of the annual report issuer's in year 2019 recorded still reaching 2.4 highest from the year 2018, while the largest increase delayed reporting in the year 2020 for financial performance year end 2019 occurs because of covid-19 pandemic. The research will be conducted on a group of manufacturing companies listed on the Indonesia Stock Exchange with period year 2015 until 2020 and not included in the delisting list until the year 2020. The results obtained audit report lag has significant effect on the stock volatility.
\end{abstract}

Keywords: Audit Tenure, Lag, Age, Size, Profitability, Solvability, Stock Volatility

\section{INTRODUCTION}

Pursuant to regulation of the Financial Services Authority (OJK) No.29/POJK. 4/2016 on annual report of Emiten or public company, stating that the issuer or public company is obliged to submit the annual report to the Financial Services Authority at the end of the fourth month after the end of the book year. This indicates that every company listed on the Indonesia Stock Exchange and has traded shares is obliged to publicly submit its financial statements to OJK no later than 120 days after the date of the annual financial statement. For stock investors, fundamental analysis of the company will be possible by looking at financial statements published annually. The time difference between the closing date of the company's financial statements by the report date of the independent auditor describes the length of time of the audit process of financial statements conducted by independent auditors. The time range between

\footnotetext{
${ }^{1}$ Corresponding author: University Nahdlatul Ulama of Surabaya, Raya Jemursari Street 57, Jemur Wonosari, Surabaya, 60237, Jawa Timur

${ }^{2}$ University Nahdlatul Ulama of Surabaya, Raya Jemursari Street 57, Jemur Wonosari, Surabaya, 60237, Jawa Timur
} 
the book close date to the reporting date of the independent auditor is often referred to as the audit report lag or Audit Report Lag (Liwe et al. 2018).

Financial statements describing information condition and performance of a company. Nevertheless, there are still many issuers (public go companies) who do not adhere to the obligations of financial statements to the public, based on the results of preliminary observations of the IDX notices from the time period of the annual issuer's announcement based on publication their financial statements in the Years 2015 2020, a percentage delay in publication of the annual report of the issuer in 2019 still reached 2.4 high from 2018 (see table 1 below), while the largest increase delayed in the year 2020 occurs because of covid-19 pandemic. It begins when there is a public statement when Indonesia exposed to the virus towards the end of March 2020 following the preventive measures of virus-chain termination conducted by the Government for all entities and communities. In this case, OJK loosened the deadline for submission of financial statements and the implementation of the general Meeting of Shareholders (GMS) for the capital market industry. This policy is an attempt to adapt to an emergency condition due to corona viruses. Submission of the annual financial report which should be at least 30 March amended to 31 May 2020 and submission of annual report which should have been no later than 30 April to 30 June 2020 .

Table 1. Delayed Public Announcement of Financial Report Periode 2014

\begin{tabular}{l|c|c|c|c|c|c}
\hline Year & $\mathbf{2 0 1 4}$ & $\mathbf{2 0 1 5}$ & $\mathbf{2 0 1 6}$ & $\mathbf{2 0 1 7}$ & $\mathbf{2 0 1 8}$ & $\mathbf{2 0 1 9}$ \\
\hline $\begin{array}{l}\text { Quantities of } \\
\text { Delayed }\end{array}$ & 49 & 52 & 18 & 17 & 10 & 24 \\
\hline Point Changed & 1 & 1.06 & 0.35 & 0.94 & 0.59 & 2.4 \\
\hline
\end{tabular}

A delay in the publication of financial statements can indicate possible problems in the company's financial statements. The financial statement is an information describing the condition of a company, which then will be an information describing the performance of a company (Fahmi 2013). Knowing the asymmetric ability of such publications in stating the objectives of financial statements presented provide information on financial position, financial performance and cash flow beneficial to most users in economic decision making for investors. Thus represent, Financial statements as a medium and a form of accountability to disclose useful information to interested parties as users of information in making economic decisions. If the financial statement shows positive value, it will attract investors to invest in the company's. Information of profit from published financial statements will lead to the increase and decrease in the price of shares called the volatility of stock prices, therefore the delay in financial report information can be interpreted by investors as a bad signal to the company (Fiatmoko and Anisykurlillah 2015).

There are many internal factors of the company affect the audit report lag, the company's age variable that is seen from the old company has recorded its company on the exchange, followed the size of the company is one factor that is predicted to be affect the audit report lag. The size of the company can be defined as the small amount of a company measured using the total wealth owned by the company. In addition, the factors affecting the audit report lag are certainly the financial ratios, namely profitability and solvency. Profitability is the company's ability to generate profits. 
Solvency is the ability of a company to pay off its debts, either long and short term (Liwe et al. 2018).

Theoretically, the delay of information (lag) will result in the negative reaction of the capital market that indirectly investors will judge it as a bad signal for the company. Signaling theory suggests when information is published, one of which is a financial report will provide signals for investors in decision making investment. If the announcement contains positive value, then hopefully market participants will react at the time of the announcement and received by the market participants. Pitaloka and Suzan (2015) stated that the audit results, the financial reporting of public companies, had substantial consequences and responsibilities. This big responsibility triggers the auditor to work more professionally.

Professionalism and performance of auditors is governed by the government regulations contained in the POJK number 13 year 2017 on the use of public accountants and public Accountant office in financial services activities that are useful to conduct more stringent additional supervision to prevent the practice of collusion to conjure financial statements against the company's financial services. In such regulations, it is regulated that the financial services institution must restrict the use of audit services from public accountants for 3 (three) years in a row. While the limitation of use of KAP services depends on the evaluation of Audit Committee. In addition, financial services institutions must use public accountants and public Accountant (KAP) registered in OJK. This will refer to the audit tenure in this research is tenure auditors that are indicated by the length of the KAP become the auditor agency of an issuer.

Based on the research gap and the phenomenon of late financial statements, especially with the policy of countermeasures Covid-19, research is conducted as an effort in knowing the intensity of the audit report lag, audit tenure, company age, company size, profitability and solvency to stock performance volatility with the moderation of KAP's reputation for the phenomenon occurring. So that researchers took the title of the research "Audit Report Lag, Audit Tenure, Age, Size, profitability and company solvency against stock performance volatility with a reputation of KAP as a moderation variable (study on companies registered in IDX reporting period year 2015-2020)".

\section{LITERATURE REVIEW AND HYPOTHESIS DEVELOPMENT}

The agency theory emphasizes the presence of conflicts between principals and agents. The principal as the party authorizes the agent to perform an activity in order to achieve the interests of the performance of the company's stock price in the stock exchange market with the increase in the value of the most active volatility that provides the value of profit (gain) for investors and this information can be seen by the audience on the website idx.co.id. Therefore, the principal needs the help of the other parties to maximize it, which is an auditor that serves as a liaison between the two parties. In the agency theory, one of the components related to Audit Report Lag is information asymmetry. In order to create the information contained in the financial statements remain reliable and relevant, the issuer or public company is required to submit the financial statements in a timely manner in order not to have the information asymmetry.

Based on the results of previous research, the trigger factors in the implementation of the audit process include the company size, profitability level, 
solvency, reputation auditing, industry classification, and so forth. Based on such research, the Audit Report Lag on this research will be controlled by the company size variables (SIZE), Solvency (DAR), and profitability (ROA).

The company's age also affects decisions in conducting the selection of auditors, as the larger the company, the more complex the financial records will take place. Large companies have lower tendency to change auditors by reason of avoiding agency cost and maintaining audit quality. The length of service delivery by an independent auditor to the client company in a row, is known as a Tenur audit.. Due to timeliness based on the theory of the agency is when the auditor and/KAP have established a relationship with the client for a long time then the possibility of the auditor will do a very small lag, because the auditor has known the characteristics of the company in the audit. Based on this, the second independent variable that is Audit Tenure will be controlled by the company's age variables already go public on IDX which will be proxy with the age.

Seeing from the religious and asymthetical theory of information, it can be said when the time efficiency and the timeliness of conducting an issuer's financial report is crucial for the company for the trust of the investors or the public as an external entity. On the KAP, the trust of the issuers go public is the most important part of the provision of their business services. Public accountant firm with good reputation tends to have competent resources to implement audit procedure more efficiently and effectively so that the audit report can be completed on time. Faster audit completion time span is the KAP's way to maintain its reputation in order not to lose client trust. KAP will tend to minimize the audit of report lag and seek to keep the auditor awake, therefore the reputation of the KAP will be a moderation variable for the audit report lag and audit Tenur.

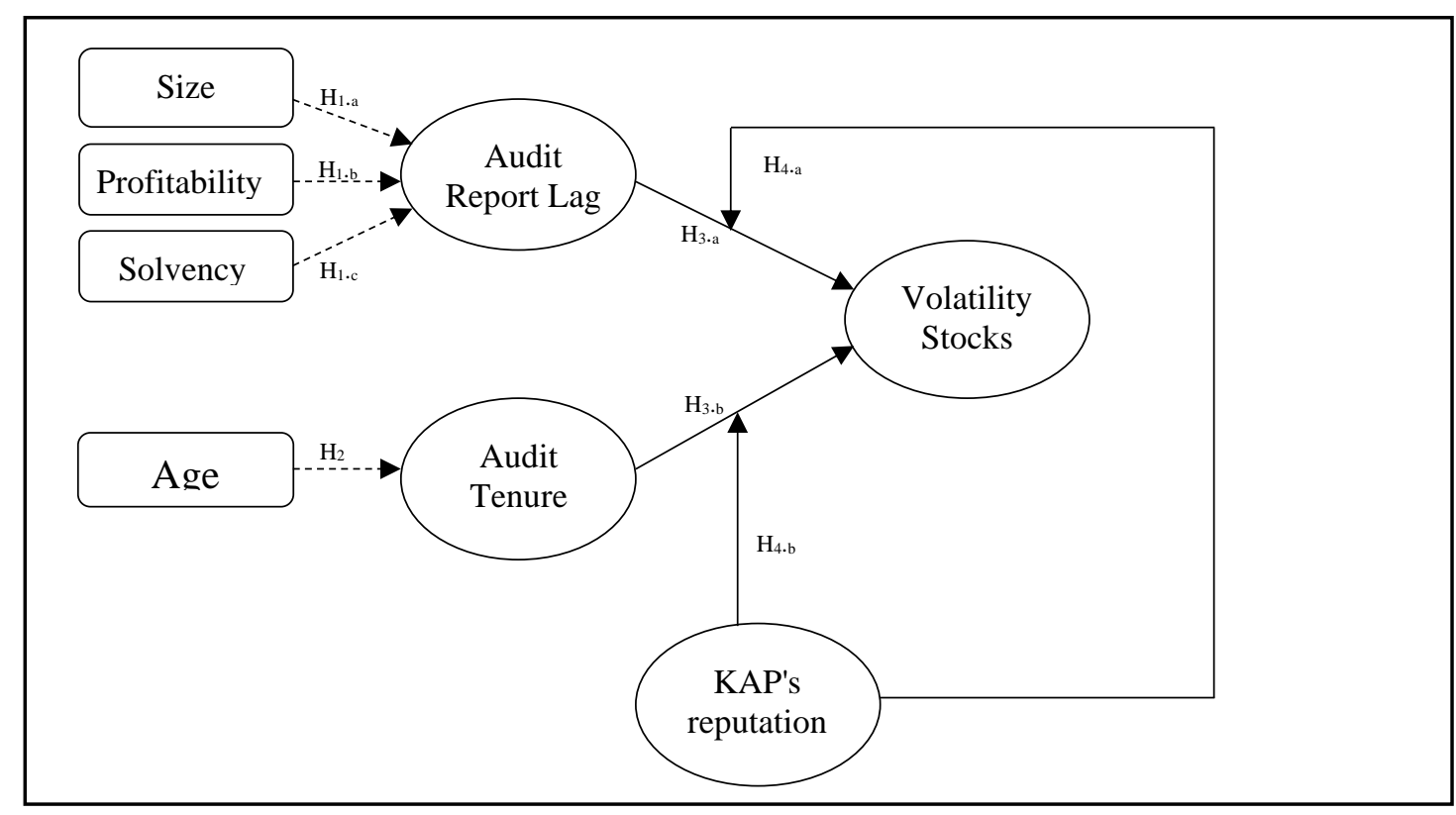

Figure 1. Conceptual Framework

\section{Hypothesis}

In this section, we will explain the development of research hypotheses on the basis of previous research. Referring to the conceptual framework, there will be four research models that will provide four research hypotheses that will be described as follows: 
H1a: The company's size is positive significantly influence the audit report lag

H1b: Profitability significant positive impact on audit report lag

H1c: Solvency significantly positive impact on the audit report lag

$\mathrm{H} 2$ : Age significant positive influence on audits tenure

H3a: Audit report lag has significant effect on volatility stocks

H3b: Audit tenure significant effect on volatility stocks

$\mathrm{H} 4 \mathrm{a}$ : The KAP reputation moderation will increase the impact of audit report lag on volatility stocks

$\mathrm{H} 4 \mathrm{~b}$ : The KAP reputation moderation will increase the impact of audit report lag on volatility stocks

\section{RESEARCH METHODS}

Data

This research is a quantitative study that uses data that have been collected in accordance with the prescribed statistical procedures. Data required in the form of annual financial report of the manufacturing company during the period 2015-2019 obtained from the secondary external parties namely the Indonesia Stock Exchange (IDX) through their site www.idx.co.id.

\section{Sample}

The samples used in this study were taken by purposive sampling methods with the aim of obtaining a representative sample according to the samples required in the study. The following criteria are used as follows: (1) Manufacturing company registered in IDX in 2015-2019. (2) Manufacturing companies that during the period 2015 - 2019 are on the list of 50 most active trading. (3) The company has the publication of the annual report period 2015 - 2019 consecutively. (4) The manufacturing company has a proportion of debt to its total set (DAR) of not more than $40 \%$. (5) The manufacturing company is included in the stock list that has a large market capital value in the exchange market. (6) The manufacturing company is over or equal to 20 years already established and listed on the Indonesia Stock Exchange.

Table 2. F-Test Research Model (1), (2), (3) and (4)

\begin{tabular}{llrrrrr}
\hline Model & $\begin{array}{c}\text { Sum of } \\
\text { Squares }\end{array}$ & \multicolumn{1}{c}{ Df } & $\begin{array}{c}\text { Mean } \\
\text { Square }\end{array}$ & F & Sig \\
\hline $\mathbf{1}$ & Regression & 125.001 & 3 & 41.667 & 1.269 & .000 \\
\cline { 2 - 7 } & Residual & 116.174 & 52 & 2.234 & & \\
& Total & 241.175 & 55 & & & \\
\hline $\mathbf{2}$ & Regression & 25.782 & 1 & 25.782 & 0.805 & .001 \\
\cline { 2 - 7 } & Residual & 6.363 & 54 & 0.118 & & \\
\cline { 2 - 7 } & Total & 32.145 & 55 & & & \\
\hline $\mathbf{3}$ & Regression & 5.074 & 2 & 2.537 & 0.623 & .037 \\
& Residual & 0.432 & 53 & 0.008 & & \\
& Total & 5.506 & 55 & & & \\
\hline $\mathbf{4}$ & Regression & 17.151 & 4 & 4.287 & 1.017 & .011 \\
\cline { 2 - 7 } & Residual & 3.267 & 51 & 0.064 & & \\
\cline { 2 - 4 } & Total & 20.418 & 55 & & & \\
\hline
\end{tabular}




\section{RESULTS AND DISCUSSIONS}

\section{Test Fit Model (F test)}

Based on table 2 statistical test result $\mathrm{F}$ is performed as a proper test for all research models, the significance value of P-value is less than the $\alpha$ value of 0.05 . Thus, it can be concluded that the entire model of this study has an influence on dependent variables and can be continued research for such regression models.

\section{Partial Test (t-Test) Research Model 1 - ARL}

Based on table 3 variable Size measured by the value of lnTotal Asset company has a coefficient value of 0.116 with a significant 0.000 or smaller than the significant value of the preset level is 0.05 . It can be concluded that Size affects the audit report lag or hypothesis 1 received. The following is also for profitability control variables with ROA proxies and solvency with the DAR proxy having a significant value of each of the 0.038 and 0.001 . And there are negative relationship. This means that if the value of DAR gets smaller then the higher the audit value report lag of a company. The overall significant value below 5\% indicates thus, the whole hypothesis of 1 fulfilled is Size, Profitability and solvency affects the audit report lag because it has a significantly smaller value of 0.05 .

Table 3. t-Test Result of Research Model 1

\begin{tabular}{|c|c|c|c|c|}
\hline \multirow[t]{2}{*}{ Model } & \multicolumn{2}{|c|}{$\begin{array}{l}\text { Unstandardized } \\
\text { Coefficients }\end{array}$} & \multirow[b]{2}{*}{$\mathrm{t}$} & \multirow[b]{2}{*}{ Sig. } \\
\hline & $\mathrm{B}$ & Std. Error & & \\
\hline 1 Constant & 1.076 & 0.079 & 13.620 & 0.000 \\
\hline Size & 0.116 & 0.025 & 4.638 & 0.000 \\
\hline Profitability & -0.595 & 0.287 & -2.073 & 0.038 \\
\hline Solvency & -0.672 & 0.194 & -3.463 & 0.001 \\
\hline
\end{tabular}

\section{Partial Test (t-Test) Research Model 2 - ATN}

Based on table 4 variable Age measured by year company established. In the results of statistical calculations $T$ test is seen that the age has a positive relationship to audit Tenur. This indicates that when the company has increased (old) age, the more it is entrusted to one public accountant to audit the financial statements. Thus, hypotheses on the Model 2 research are acceptable, because it has a significantly smaller value than 0.05 .

Table 4. t-Test Result of Research Model 2

\begin{tabular}{|c|c|c|c|c|}
\hline \multirow[t]{2}{*}{ Model } & \multicolumn{2}{|c|}{$\begin{array}{l}\text { Unstandardized } \\
\text { Coefficients }\end{array}$} & \multirow[b]{2}{*}{$\mathrm{t}$} & \multirow[b]{2}{*}{ Sig. } \\
\hline & $\mathrm{B}$ & Std. Error & & \\
\hline Constant & 2.603 & 11.876 & 0.219 & 0.000 \\
\hline Age & 0.894 & 0.914 & 0.978 & 0.036 \\
\hline
\end{tabular}

\section{Partial Test (t-Test) Research Model 3 - VPS}

Based on table 5 variable Audit Report Lag is noticeable when ARL has an influence on stock volatility. While the tenure audit has no effect on the stock volatility because it has a value of more than $5 \%$. 
Table 5. t-Test Result of Research Model 3

\begin{tabular}{|c|c|c|c|c|}
\hline \multirow[t]{2}{*}{ Model } & \multicolumn{2}{|c|}{$\begin{array}{l}\text { Unstandardized } \\
\text { Coefficients }\end{array}$} & \multirow[b]{2}{*}{$\mathrm{t}$} & \multirow[b]{2}{*}{ Sig. } \\
\hline & B & Std. Error & & \\
\hline Constant & 3.668 & 6.093 & 0.602 & 0.060 \\
\hline ARL & 5.106 & 2.025 & 2.521 & 0.035 \\
\hline ATN & -1.572 & 0.544 & -2.889 & 0.381 \\
\hline
\end{tabular}

Partial Test (t-Test) Research Model 4 - VPS With reputation moderation KAP

Based on table 5 variable Audit Report Lag is seen only ARL that has an influence on the stock volatility. While the tenure audit and moderation variables have no effect on the stock volatility because it has a significant value of more than 5\%. So the null hypothesis is accepted and the 4 hypothesis is rejected.

Table 5. t-Test Result of Research Model 4

\begin{tabular}{|c|c|c|c|c|}
\hline \multirow[t]{2}{*}{ Model } & \multicolumn{2}{|c|}{$\begin{array}{l}\text { Unstandardized } \\
\text { Coefficients }\end{array}$} & \multirow[b]{2}{*}{$\mathrm{t}$} & \multirow[b]{2}{*}{ Sig. } \\
\hline & $\mathrm{B}$ & Std. Error & & \\
\hline Constant & 113.323 & 25.652 & 4.418 & 0.000 \\
\hline ARL & 3.366 & 3.785 & 0.889 & 0.012 \\
\hline ATN & -2.604 & 1.209 & -1.254 & 0.093 \\
\hline ARL*KAP & -0.983 & 0.913 & -1.077 & 0.283 \\
\hline ATN*KAP & -1.572 & 0.544 & -2.889 & 0.381 \\
\hline
\end{tabular}

\section{Discussion}

\section{Effect of company size (Size) on Audit Report Lag}

Based on the results of the test is known that Size has a significant effect on Audit Report Lag. The size of the company has a direct or positive relationship with the Audit Report Lag, where the larger the size of the company then the Audit Report Lag is increasing. The larger the size of the company, the more you get the attention of both investors and government (Kieso et al. 2019).

Larger companies are considered to settle their account audits earlier than small companies because they have strong control. Related to this, big companies are required to report their financial statements faster. But regardless of the company that has a total asset that is categorized as a large company. Large Total assets will also take longer for the auditor to audit the company. It can not be dihnfrom although companies that have a good image to shorten ARL.

\section{Impact of profitability on Audit Report Lag}

Based on the results the test made known that profitability has significant effect on Audit Report Lag, the profitability has a T-count value of 2,073> 2.032 and a significance value of $0.038<0.05$. Thus $\mathrm{H} 1$ is received according to the result of partial hypothesis test ( $t$ test). Profitability has an inverse relationship with Audit Report Lag, where the greater the profitability then Audit Report Lag is decreasing. Companies that have a profit increasingly have the ability to pay a higher audit fee, so that the company can determine the public accounting firm (KAP) that can perform the audit completion faster. In addition companies that experience high levels of 
profitability (good news) tend to expect completion of audits as quickly as possible and will not delay the publication of their financial statements. Thus, companies that get good news tend to be faster in delivering financial statements compared to companies that have low profitability or losses.

\section{Solvency effect on Audit Report Lag}

Solvency is one of the ratios to show the company's financial health, but not deciding whether the company's performance is assessed well or not, because when the company is able to obtain a high profit the company is able to pay its debts. The high debt of the company tends to require a long audit time, but if there is no fault or fraud against the company's debt registration, there is no need for thorough audits that will affect the Audit Report Lag.

\section{Influence of Age on Audit Tenure}

The results proved that the company's age (old) was formed and listed on the stock Exchange was positively influential towards the Audit Tenur. The company's age also affects decisions in conducting the selection of auditors, as the larger the company, the more complex the financial records will take place. Large companies have lower tendency to change auditors by reason of avoiding agency cost and maintaining audit quality. The length of service delivery by an independent auditor to the client company that is successively established is known as the audit of Tenur. Due to timeliness based on the theory of the agency is when the auditor and/KAP have established a relationship with the client for a long time then the possibility of the auditor will do a very small lag, because the auditor has known the characteristics of the company in the audit.

\section{Effect of Audit Report Lag and Audit of Tenur on stock volatility in Stock Market}

The results proved that the audit report lag was significantly positive towards stock volatility in exchanges. This indicates that the faster to publish financial statements, the more public trust the issuer. Thus, the smaller the ARL value is getting better. This corresponds to the signal theory associated with the information contained on the company's financial statements. The better the financial condition of the company, it will give signals to the market, so that the market can assess the good and bad companies, this is what then triggers the volatility of stocks on the exchanges. The return with the Audit report lag, for the audit of the Tenur, does not trigger signals on the market. This is evidenced by the results of the insignificance of an audit to stock volatility.

\section{Effect of Audit Report Lag and Audit Tenur of equity volatility in exchanges with KAP's reputation as moderation variables}

The results proved that only an audit report lag was significantly positive towards stock volatility in exchanges. While the audit of Tenur with the addition of the reputation moderation of KAP has no meaningful influence for stock volatility in exchanges. Signals on the market. This is evidenced by the results of the insignificance of an audit to stock volatility. 


\section{CONCLUSIONS}

The results of the evaluation of the research model and the hypothesis proposed in this study resulted in the following conclusions:

(1) The first hypothesis test result (H1) indicates that the size of the company has a positive influence, while profitability and solvency negatively affect the audit report lag as the basis for delivering audit reports.

(2) Second hypothesis testing result $(\mathrm{H} 2)$ indicates that the age of the company (AGE) affects the Tenur audit as the basis of the company conducting financial reporting on the public.

(3) The result of the third hypothesis test (H3) indicates that only the audit report lag that affects the stock volatility in the stock market.

(4) The result of the fourth hypothesis test $(\mathrm{H} 4)$ shows that even with the reputation moderation of the KAP, but apparently the reputation of the KAP as moderation variables and Tenur audits do not have a significant influence on the stock volatility.

\section{RERERENCES}

Fahmi, I. 2013. Analisis Laporan Keuangan Bandung: Alfabeta: CV.

Fiatmoko, A. L., and I. Anisykurlillah. 2015. Faktor-Faktor yang Berpengaruh Terhadap Audit Delay pada Perusahaan Perbankan. Accounting Analysis Journal 4 (1).

Kieso, D. E., J. J. Weygandt, T. D. Warfield, I. M. Wiecek, and B. J. McConomy. 2019. Intermediate Accounting, Volume 2: John Wiley \& Sons.

Liwe, A. G., H. Manossoh, and L. M. Mawikere. 2018. Analisis Faktor-Faktor yang Mempengaruhi Audit Delay (Studi Empiris pada Perusahaan Property dan Real Estate yang Terdaftar di Bursa Efek Indonesia). GOING CONCERN: JURNAL RISET AKUNTANSI 13 (02).

Pitaloka, D. F., and L. Suzan. 2015. Pengaruh Ukuran Kap, Opini Audit, Ukuran Perusahaan, Dan Profitabilitas Terhadap Audit Delay (studi Kasus Pada Perusahaan Go Public Yang Konsisten Terdaftar Di Indeks Lq45-bursa Efek Indonesia Tahun 2009-2013). eProceedings of Management 2 (2). 